\title{
Matching productivity to resource availability in a small predator, the stoat (Mustela erminea)
}

\author{
Carolyn M. King, Piran C.L. White, Dan C. Purdey, and Barry Lawrence
}

\begin{abstract}
Stoats (Mustela erminea), introduced to New Zealand in the late nineteenth century, are common in New Zealand beech (Nothofagus sp.) forests, where populations of feral house mice (Mus musculus) fluctuate between years much as voles do in the northern hemisphere. We present new field evidence and two models demonstrating $(i)$ a strong correlation between density indices for young stoats in summer and for mice in the previous spring, and (ii) a significant linear relationship between productivity per female and spring density of mice up to 25 mice captures per 100 trap-nights. These models confirm that short-lived small mustelid predators dependent on fluctuating populations of prey have evolved means of matching their productivity to the prospects of success across a wide range, from total failure in rodent crash years to $>12$ independent young per female in rodent peak years. We suggest that the enhanced reproductive success of female stoats when rodents are abundant is due to a combination of critical improvements in both the reproductive physiology and the foraging behaviour of female stoats in rodent peak years. Conversely, a drastic shortage of rodents increases the mortality of embryos and nestlings, while the adult females are able to survive, and even remain relatively fat, on other foods.
\end{abstract}

Résumé : Les hermines (Mustela erminea) introduites en Nouvelle-Zélande à la fin du XIX ${ }^{\mathrm{c}}$ siècle sont abondantes dans les forêts de hêtres de Nouvelle-Zélande (Nothofagus sp.) où les populations de souris communes (Mus musculus) sauvages subissent des fluctuations d'année en année, un peu comme chez les campagnols dans l'hémisphère nord. Nous présentons ici des données recueillies en nature et deux modèles qui démontrent qu'il y a (i) une forte corrélation entre les coefficients de densité des jeunes hermines en été et ceux des souris au printemp précédent et (ii) une relation linéaire significative entre la productivité par femelle et la densité des souris au printemps jusqu'à une densité de 25 captures de souris par 100 pièges-nuits. Les modèles confirment que les petits mustélidés prédateurs à longévité limitée, qui dépendent des populations fluctuantes de proies, ont développé des moyens d'assortir leur productivité à leurs chances de succès sur une grande étendue de conditions, d'un échec total les années de déclin des populations, à $>12$ rejetons indépendants par femelle les années de pointe des rongeurs. Nous croyons que le succès plus grand de la reproduction des femelles les années d'abondance des rongeurs est attribuable à une combinaison d'améliorations critiques de la physiologie de la reproduction et du comportement de quête de nourriture des hermines femelles les années de pointe des rongeurs. Inversement, une carence grave de rongeurs augmente la mortalité des embryons et des rejetons au nid, mais les hermines adultes sont capables de survivre et même de demeurer relativement grasses avec un régime alimentaire différent.

[Traduit par la Rédaction]

\section{Introduction}

In many terrestrial ecosystems, the pulsing of resources, caused, for example, by synchronized heavy fruiting (mast) of trees or cyclic population fluctuations of prey species introduces very substantial year-to-year variation in the distribution of energy through the food web (Ostfeld and Keesing 2000). For consumers dependent on such pulsed resources, the chances of producing viable offspring will consequently also vary from year to year. In an unstable environment we would expect some means of matching reproductive effort to the probability of success to be an important component of reproductive strategy (e.g., Mappes and Ylonen 1997; Pitcher et al. 1998; Brommer et al. 2002). The cost of missing or delaying opportunities to match effort to resources is particularly significant for small, short-lived animals whose average life-span is shorter than the average interval between high-resource years.

The stoat or short-tailed weasel (Mustela erminea) is a small predator $(50-450 \mathrm{~g})$ that has evolved to specialize on hunting unstable populations of small rodents in the boreal regions of the northern hemisphere (King 1989). Yet the reproductive cycle of the stoat includes an obligate 9- to 10month diapause (delay in implantation) (Wright 1942). Hence,

Received 1 November 2002. Accepted 19 Fcbruary 2003. Published on the NRC Research Press Web site at http://cjz.nrc.ca on 30 April 2003.

C.M. King ${ }^{1}$ and D.C. Purdey. Centre for Biodiversity and Ecological Research, Private Bag 3105, University of Waikato,

Hamilton, New Zealand.

P.C.L. White. Environment Department, University of York, Heslington, York YO10 5DD, U.K.

B. Lawrence. Malaghans Road, RD 1, Queenstown, New Zealand.

${ }^{1}$ Corresponding author (e-mail: c.king@waikato.ac.nz). 
young born in any given year were conceived in the previous year, and the availability of food supplies at birth is unknown at conception. The stoat also exhibits sexual bimaturism as well as sexual dimorphism, both to a very pronounced degree. The young females are extremely precocious, and are fertilized in the nest by an adult male before their eyes open; young males reach puberty only at 10 11 months of age (King and Moody 1982b; Ternovsky 1983). Therefore, both sexes must survive to $>1$ year old to produce or father any young, but first-year mortality is high and very variable (55-92\%) (Powell and King 1997).

These curious features of reproduction in stoats raise the important question of how individual stoats match fertility to the prospects of raising the optimum number of young, or even any. In good years the single annual litter may be large, up to 18 embryos or 14 kits born (King 1989), even though the large cohorts of young produced in good years face greater competition for food and territories from the age of independence. In poor years a female producing too large a litter would be likely to lose them all. One would expect an individual female stoat to produce as many young as she could feed when food is abundant, yet not to risk her future prospects by producing too many. Where resources vary in quality, and those of the best quality fluctuate through a wide range of abundance, the question of theoretical interest is "under what circumstances should a short-lived predator confined to producing only one litter a year risk reducing litter size to zero?"

The only small rodents present in southern beech (Nothofagus sp.) forests in the South Island of New Zealand are introduced house mice (Mus musculus) and ship rats (Rattus rattus). The populations of these rodents fluctuate in response to the masting cycle of the beech trees (King 1982; King and Moller 1997; Choquenot and Ruscoe 2000; Ruscoe 2001 ), and stoats (also introduced) exhibit a significant functional response to them (King 1983; Murphy and Dowding 1995) while continuing to take other foods as well. Other prey species hunted by stoats also respond to a seedfall. Seed-eating birds such as the yellow-crowned parakeet (Cyanoramphus auriceps) (Elliott et al. 1996) and kaka (Nestor meridionalis) (Wilson et al. 1998) breed well in mast years, and introduced finches migrate to the forest to feed on beech seed (Wardle 1984, p. 241). Litter-feeding insects such as lepidopteran larvae also benefit from the addition of spent male flowers to the litterfall. They are not often eaten directly by stoats (King and Moody 1982a; Murphy and Dowding 1995), but the increase in their numbers precedes and may assist the increase in mice (Fitzgerald et al. 1996). As Murphy and Dowding (1995) and Fitzgerald and Gibb (2001) point out, it may be that increases in mouse, bird, and invertebrate densities all contribute to the high productivity of stoats following a seedfall.

There is considerable geographic variation in these relationships, but mice are the most conspicuous common factor in all observed cases. Long-term correlations between variations in stoat and mouse populations (King 1983; Wilson et al. 1998), and between the breeding success of stoats and variations in mouse populations (King 1981), suggest that mice are a key resource that determines breeding success for beech-forest stoats. Rats may well contribute to this effect where they are present, but the correlations still hold in beech forests (such as Craigieburn Forest Park and the Grebe Valley) where rats are scarce or absent (King 1983).

All young stoats in New Zealand are born over a short period in spring, and by about a month before the summer solstice virtually all females of all ages have been mated and are carrying the small corpora lutea typical of the diapause phase of pregnancy (King and Moody 1982b). The mean ovulation rate is relatively constant from year to year $(8-10$ ova released per female) but with wide variance (King 1981). Diapause lasts until about 6-8 weeks after the winter solstice, when the lengthening days pass a critical threshold, triggering implantation. The number of young born depends not on fecundity (ovulation rate) but on fertility (litter size). Fertility is adjusted to environmental conditions by sequential juvenile mortality, reducing as necessary the number of blastocysts implanted, the number of cmbryos that survive to full term, and the number of nestlings that survive to independence. Implantation is therefore the first of several critical points in the stoat's reproductive cycle when litter size for the current season is determined (King and Moody $1982 b$; King 2002). The post-implantation phase of pregnancy lasts 28 days (King and Moody 1982b; Ternovsky 1983).

After a heavy seedfall, mice continue to breed over winter (King 1982), and are abundant (King 1983) and still breeding by the time the complex series of pre-implantation changes begins. King (1981) demonstrated a simple rank correlation between the productivity of a local stoat population (measured as the number of young stoats caught per 100 trapnights in summer) and mouse density in spring. Conversely, after independence, the young stoats born during the mouse population peak not only suffer higher mortality throughout their first year of life (Powell and King 1997), but also find that, by the time they are ready to produce their own first litter, the conditions are very unfavourable. King (1981) found indirect evidence that, in the "crash" years following a postseedfall peak in mouse numbers, some female stoats (11 of 34 caught in the spring of crash years) lost their entire litter, though they survived on other foods themselves.

Stoats are serious alien pests on conservation lands in New Zealand, where the future survival of several iconic native species depends on finding humane and efficient means of controlling them (Basse et al. 1999). The recent realisation of this danger has stimulated intense research on stoats, including their reproductive physiology, in case a practicable method of fertility control can be developed (Norbury 2000).

In order to develop technology for inducing infertility artificially, it would help to understand what induces it naturally. Therefore, in this paper we describe a brief, intensive field study documenting a season of natural total reproductive failure in a previously undisturbed stoat population during the decline phase of the beech cycle. We present two new models demonstrating the key relationships between stoat productivity and resource availability by relating the density index of mice in spring to (i) the density index of young stoats in summer and (ii) the number of young stoats produced per adult female.

\section{Study area}

New Zealand is in the southern hemisphere, so the turn of the calendar year is in summer not in winter. The seasons 
Fig. 1. Map of the South Island of New Zealand, showing locations mentioned in the text.

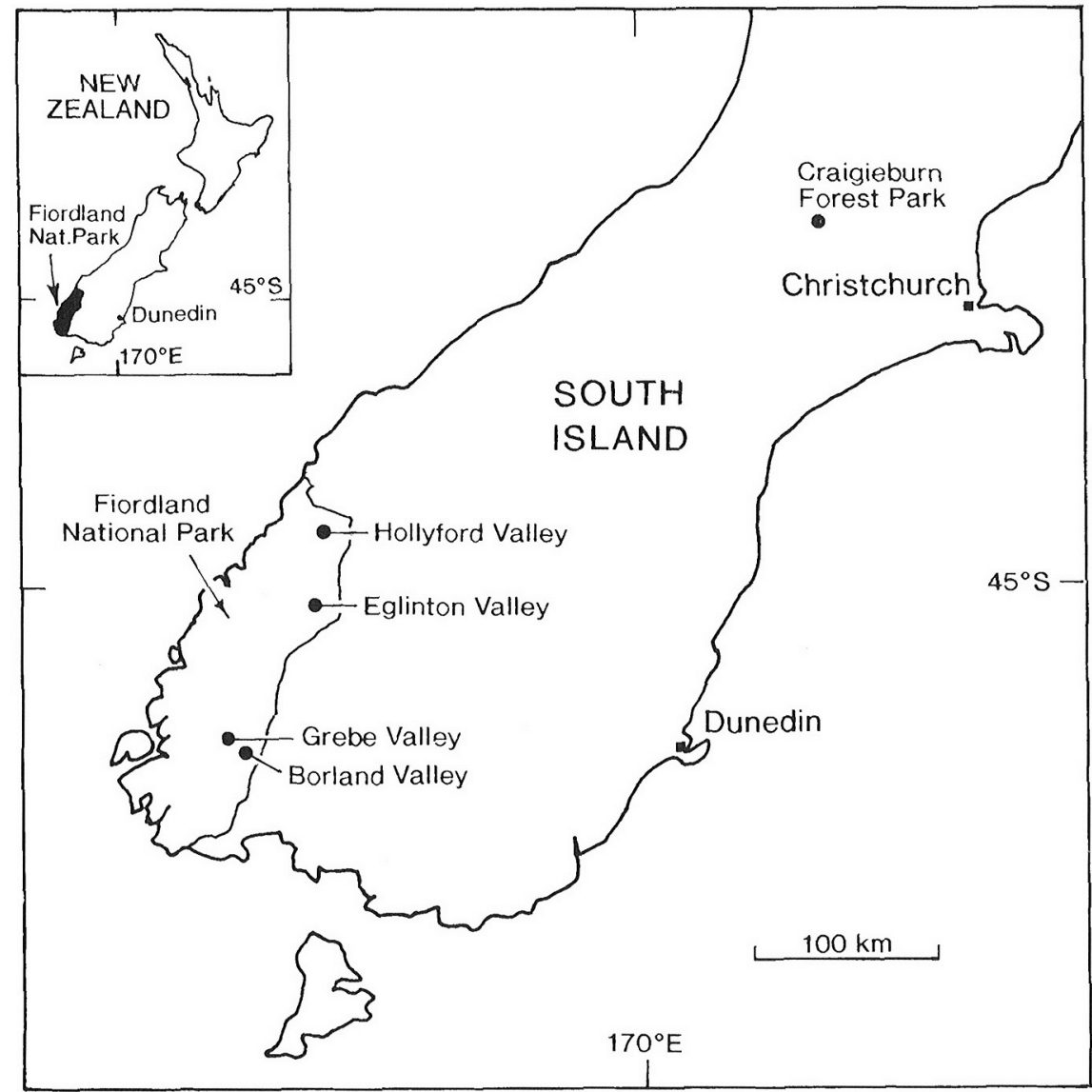

Table 1. Density indices for feral house mice (Mus musculus) and stoats (Mustela erminea) recorded during this study.

\begin{tabular}{|c|c|c|c|c|c|c|}
\hline & \multicolumn{3}{|c|}{ Borland Valley } & \multicolumn{3}{|c|}{ Grebe Valley } \\
\hline & $\begin{array}{l}\text { No. of } \\
\text { captures }\end{array}$ & $\begin{array}{l}\text { Total } \\
\text { trap-nights }^{a}\end{array}$ & $\begin{array}{l}\text { Captures per } 100 \\
\text { trap-nights }{ }^{a}\end{array}$ & $\begin{array}{l}\text { No. of } \\
\text { captures }\end{array}$ & $\begin{array}{l}\text { Total } \\
\text { trap-nights }\end{array}$ & $\begin{array}{l}\text { Captures per } 100 \\
\text { trap-nights }^{a}\end{array}$ \\
\hline \multicolumn{7}{|l|}{ Mice } \\
\hline November 1999 & 68 & 110 & $62(52.1-70.9)$ & - & - & - \\
\hline February 2000 & 51 & 160 & $31.9(24.7-39.7)$ & 50 & 152 & $32.9(25.5-41.0)$ \\
\hline December 2000 & 0 & 213 & 0 & 1 & 201.5 & $0.49(0.01-2.7)$ \\
\hline \multicolumn{7}{|l|}{ Stoats } \\
\hline
\end{tabular}

Note: Values in parentheses are $95 \%$ confidence intervals.

aCorrected for unavailable traps (from Purdey 2002).

are reversed by 6 months from those in the northern hemisphere, and are conventionally defined as follows: summer: December, January, and February; autumn: March, April, and May; winter: June, July, and August; spring: September, October, and November.

Our fieldwork in the summer of 2000-2001 was done in the Grebe and Borland valleys $\left(45^{\circ} 45^{\prime} \mathrm{S}, 167^{\circ} 30^{\prime} \mathrm{E}\right)$ at the southern end of Fiordland National Park, South Island, New Zealand (Fig. 1). The two valleys are linked by a pass at $950 \mathrm{~m}$ altitude and traversed by a $38 \mathrm{~km}$ long gravel track. There was no history of systematic stoat-control operations in that area, except for sporadic local protection of the mohua or yellowhead (Mohua ochrocephala), an endangered forest passerine (O'Donnell et al. 1996).

In autumn 1999 there was a heavy beech seedfall through- out Fiordland National Park. Standard density-index lines for mice (King 1983) set in the following spring (November 1999) showed that mice were superabundant (Table 1). By late summer (February) of 1999-2000, the mouse density indices had declined substantially, but the indices recorded then were still higher in both valleys than the average postseedfall mouse population peak previously observed in other beech forests (Murphy and Pickard 1990). Over the following winter the mouse population collapsed, and by spring (December) 2000 they were virtually absent from our index lines in both valleys, though still present in patches elsewhere (Purdey 2002).

The model we present here combines results from the Grebe and Borland valleys obtained in January 2001 with previously published data (King 1983) collected during the 
Fig. 2. Frequency distribution of year classes of stoats (Mustela erminea) kill-trapped in the Grebe and Borland valleys, southern Fiordland National Park, in January 2001, two summers after a heavy seedfall in 1999 (solid bars; $n=63$ ) compared with that from a typical irruption year in the Eglinton Valley, northern Fiordland National Park, in December-February 1976-1977, the summer following a heavy seedfall in 1976 (shaded bars; $n=66$ ).

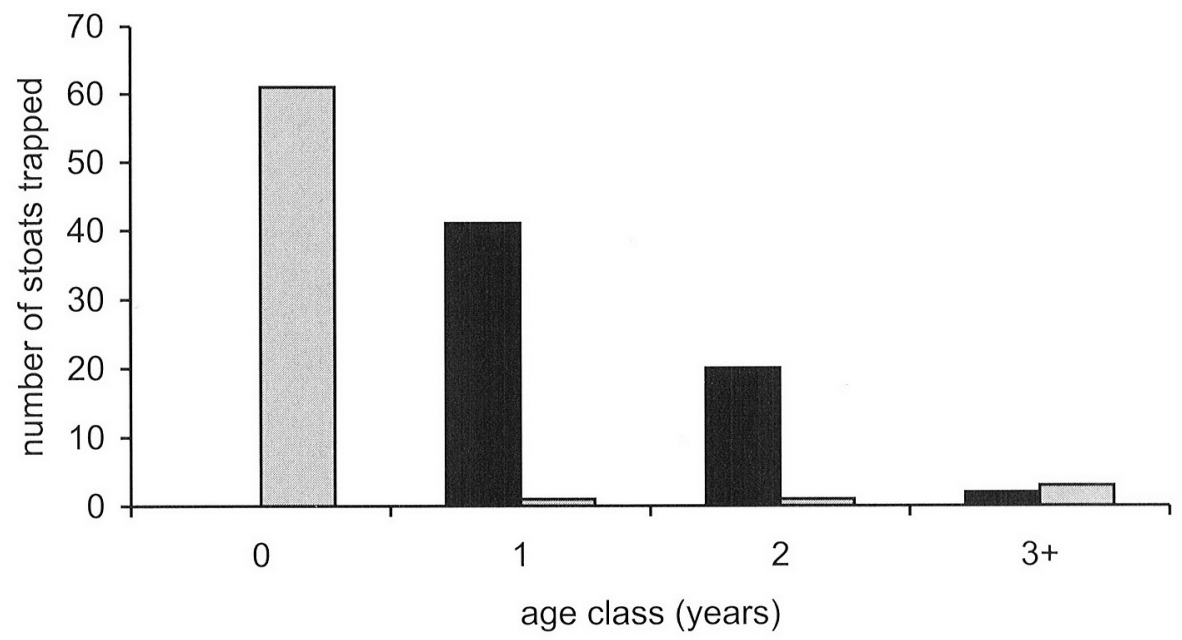

1970s from regularly cropped populations in the Eglinton and Hollyford valleys, $85 \mathrm{~km}$ away at the northern end of the Park, and from Craigieburn Forest Park in the central South Island (Fig. I).

\section{Methods}

We used a single transect of 30 sampling stations set at 1 $\mathrm{km}$ intervals (Brown and Miller 1998) for 12 days from 16 to 28 January 2001 . At each of two trap sites per station, we placed a double trap tunnel containing two Fenn (kill) traps (King and Edgar 1977), totalling four per station. Kill-trapping was necessary to collect carcasses for age determination and to meet other objectives of the study. Since stoats are alien pests in New Zealand, kill-trapping to reduce their populations and enhance native ecosystem values is encouraged, especially in national parks.

We determined the ages of captured stoats by counting the cementum annuli in the canine teeth, the number of which has been correlated with known or part-known age by Grue and King (1984). The single annual line is added in autumn and winter, starting in April at about 6-7 months of age. Lower canine teeth of all stoats collected in January 2001 were sectioned and read by Matson's Laboratory, Milltown, Montana, U.S.A.

We estimated the fat content of each carcass using a ranking system from 0 (no fat) to 4 (highest fat content) based on a visual estimate of the amount of fat accumulated around the spine, kidneys, groin, and intestines. An average of values for these four areas gave the overall fat index for each animal.

Data on the age structure of the Grebe-Borland population sampled in 2000-2001 were analysed along with equivalent data from earlier studies (Powell and King 1997). The number of young stoats caught per 100 trap-nights in summer (correcting for unavailable traps) and the ratio of young to adult females captured (a measure of productivity) were related to mouse-capture rates in spring by means of linear regression models of the form $y=\beta x+c$, using SPSS version 10 . We checked the residuals of each regression for de- viations from the assumptions of normality, linearity, and homoscedasticity (Tabachnick and Fidell 1996).

Mouse-capture rates in all study areas were estimated using controlled transects of snap (kill) traps run for 3 nights every 3 months. Trap tunnels with one mouse trap and onc rat trap each were set along fixed lines (36 tunncls at 50-m intervals), according to the then standard routine (King 1982 , 1983).

\section{Results}

Between 16 and 28 January 2001, 63 stoats were killtrapped and two carcasses (partially eaten, presumably by other stoats) were recovered (37 males, 28 females). All were classed as adults from their skulls, and all the 63 teeth sectioned showed between 1 and 3 annual lines in the dental cementum. There were no young of the 2000-2001 scason in this sample, taken a ycar after the last mouse irruption in 1999-2000, by contrast with a typical sample taken cluring a mouse irruption (9 months after a scedfall) (Fig. 2). Instead, the large cohort of young stoats born in the study area during the 1999-2000 mouse population peak appeared in this sample as 1-year-olds.

The fat index of the carcasses was $2.8 \pm 0.9$ (mean $\pm \mathrm{SE}$; $3.0 \pm 0.9$ in 35 males and $2.7 \pm 0.8$ in 28 females)

In the combined dataset from 2000-2001 and earlier (Powell and King 1997) there was a highly significant positive relationship between the rate of capture of young stoats in summer and mouse-density indices taken in the previous spring, 3 months earlier (Fig. 3; $F_{|1.11|}=46.77, R^{2}=0.81$, adjusted $\left.R^{2}=0.79, P<0.001\right)$. None of the data points in the model had a Mahalanobis distance greater than 3.47, a leverage value greater than 0.29 , or a Cook's distance greater than 0.44 .

There was also a significant positive relationship between the number of young stoats per adult female caught and the mouse-density index in spring (Fig. $4 ; F_{|1.10|}=18.19, R^{2}=$ 0.65 , adjusted $\left.R^{2}=0.61, P=0.002\right)$. None of the data points had a Mahalanobis distance greater than 3.11, a leverage 
Fig. 3. Relationship between density indices (captures per 100 trap-nights) for young stoats in summer and for feral house mice (Mus musculus) in spring. The graph shows the best fit line and $95 \%$ upper and lower confidence intervals for a regression equation of the form $y=\beta x+c$, where $\beta=0.24 \pm 0.04(t=6.84, P<0.001)$ and $c=0.20 \pm 0.36(t=0.56, P=0.59)$.

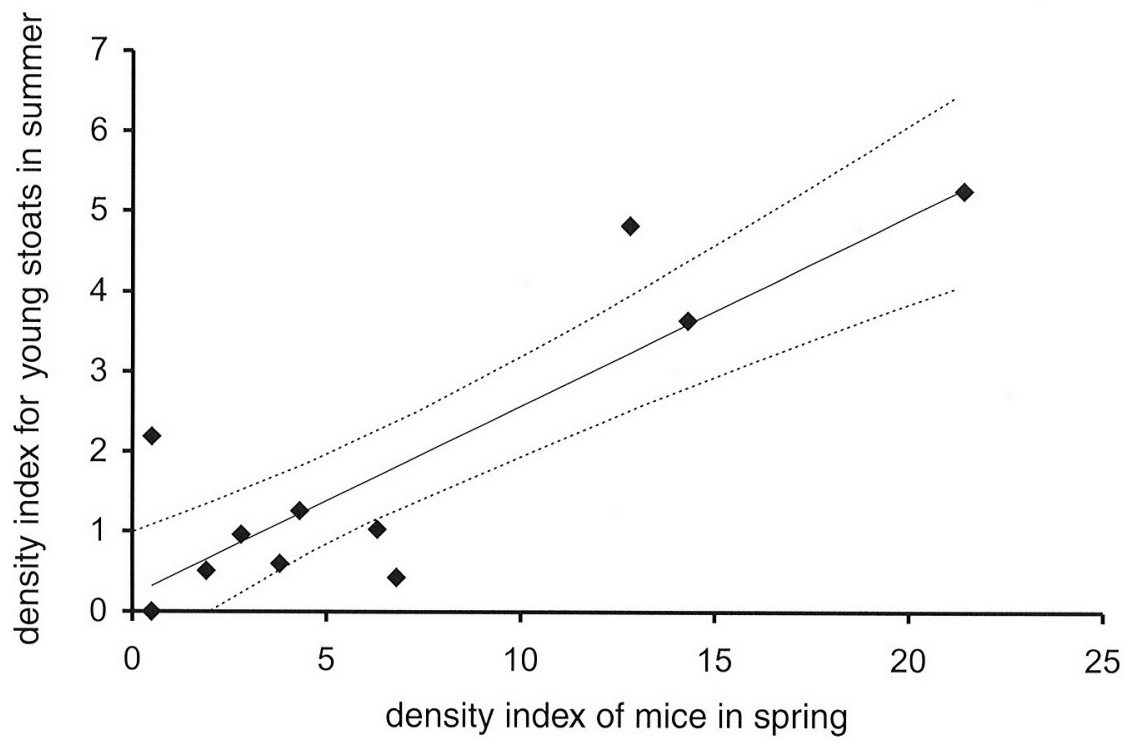

Fig. 4. Relationship between the number of young per adult female stoat trapped and the density index (captures per 100 trap-nights) of mice in spring. The graph shows the best fit line and 95\% upper and lower confidence intervals for a regression equation of the form $y=\beta x+c$, where $\beta=0.81 \pm 0.19(t=4.27, P=0.002)$ and $c=1.32 \pm 2.03(t=0.65, P=0.53)$.

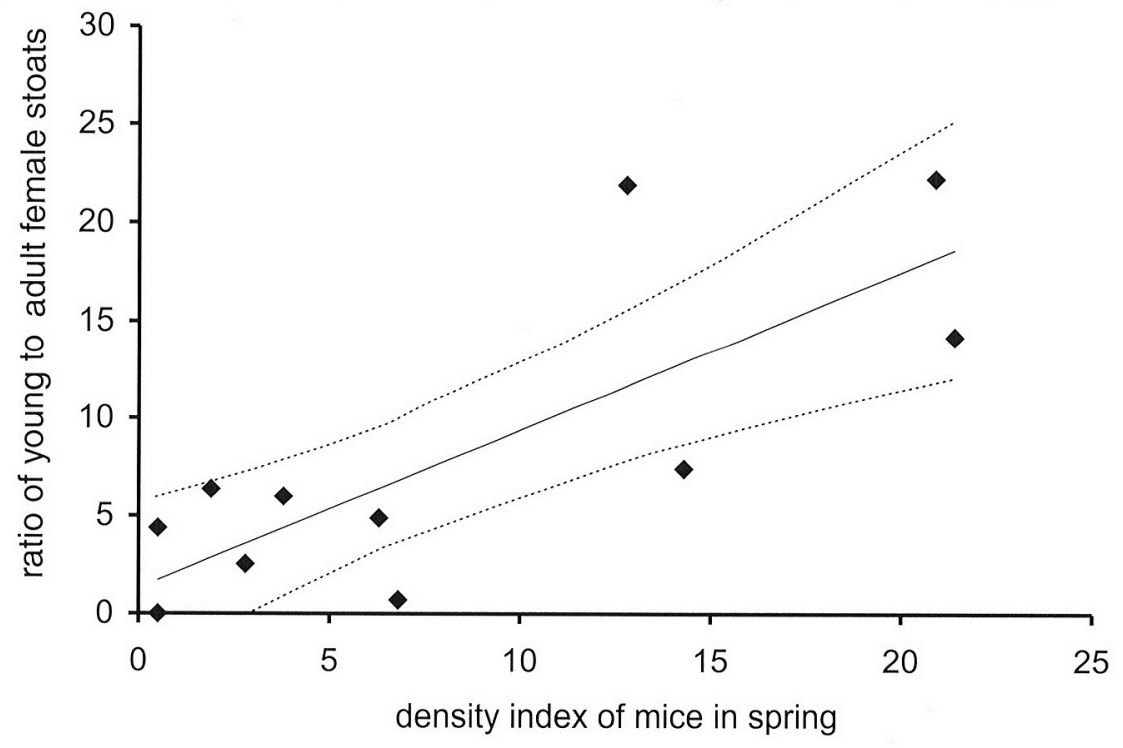

value greater than 0.28 , or a Cook's distance greater than 0.37 .

\section{Discussion}

\section{Modelling the relationship}

The new data presented in this paper extend and explore in more detail the known correlation between the summer production of juvenile stoats and the spring density index of mice (King 1981, 1983). The regressions (Figs. 3 and 4) combine data from independent studies, but their significance and generalizability (as indicated by the small difference between $R^{2}$ and adjusted $R^{2}$ values) confirm that differences in sampling method (trap type, spacing, etc.) are relatively unimportant compared with the strength of the overall relationship between stoat productivity and availability of mice. The most extreme possible difference in sampling method is that between livetrapping and killtrapping (i.e., sampling with and without replacement, respectively), but even that does not affect the proportion of young caught provided the comparison is controlled for season. For example, in two samples from high-density summer populations collected from the same area, one by means of each method, there was no significant difference $\left(\chi^{2}=1.43\right.$, $P>0.05)$ in the proportions of young stoats caught (Powell and King 1997). Prolonged kill-trapping may well reduce the longevity of adults in trapped populations compared with that of adults in untrapped populations; however, the distribution of adult year classes is not relevant in this paper, which is concerned only with the proportion of young of the 
current year. We therefore conclude that trapping history has less effect on the proportion of young in a summer sample than the productivity of the most recent breeding season.

The model predicts reasonable values for maximum productivity per female stoat (ratio of young to adults caught in summer). The maximum recorded embryo count for stoats is 18 (King 1989), and the model predicts that $17.5 \pm 6.1(95 \%$ $\mathrm{CI}$ ) young per female should be produced at a mouse-density index of 20 captures per 100 trap-nights in spring. Such high productivity is possible when mice are abundant, because a high mouse population offers an ideal prey resource for nursing stoats: mice are easy to find, no threat to kill, light to carry back to the nest, and rapidly replaced. On the other hand, when mice are scarce, home ranges have to be larger (Murphy and Dowding 1995), hunting takes more effort and time, and substitute foods such as invertebrates and carrion may be insufficient to meet the combined energy demands of pregnancy, lactation, and hunting over extended areas. In 5 of 13 sets of embryos counted by King and Moody (1982b), at least some were being resorbed; in one female, only one of eight embryos was viable.

Figures 3 and 4 show a linear increase in stoat productivity with mouse-density indices up to about 25 captures per 100 trap-nights. In fact, mice may reach much higher densities than this (Table 1), but the relationship demonstrated here could not be extended much beyond the existing data. The maximum potential litter size in the birth season was set in the previous season, and physiological constraints would certainly set an upper limit to the number of embryos that could be brought to full term, regardless of further increases in mouse density.

\section{Environmental control of fertility in stoats}

Implantation is possible only when an activated blastocyst coincides with a receptive uterus (Renfree and Shaw 2000), and the process of establishing a foetus involves a very complex series of reciprocal signalling (Paria et al. 2002). Later intra-uterine processes and nestling survival are strongly influenced by environmental conditions in spring and early summer via their effects on the hypothalamic-pituitary-ovarian axis (Wade et al. 1996). The details of how these interactions are controlled vary among species, and few have been directly studied in stoats (Norbury 2000). The average number of blastocysts per female available in late winter is $8-10 \mathrm{ev}$ ery year (King 1981), but the ratio of young stoats caught per female in summer varies over a much wider range (Fig. 4), presumably because of variation in the extent of intra-uterine and nestling mortality among years. The spectrum of possible results is presented in Fig. 2, from the extensive natural failure to produce any young at all in the 2000-2001 season to the massive production of young in a typical irruption year such as 1976-1977.

From extensive existing data reported by King (1981) it is reasonable to assume that all the female stoats we handled in the summer of 2000-2001 would have been fertilized before dispersal, as usual (King and Moody 1982b). Their own normal complement of blastocysts, due to implant and be born in August 2000, must have been drastically reduced during the journey from the uterus to the nest to trappable age. The ratio of young to adults in this sample, $0: 76$, implies the near total loss of all young by adults of all ages attempting to raise litters in the Grebe and Borland valleys during the summer of 2000-2001. Murphy and Dowding (1995) observed a comparable ratio (0:37) in the Eglinton Valley in 1991-1992, 21 months after a heavy seedfall in 1990. In both cases the losses were probably due to failure to implant, to resorption, or to failure of the female to supply enough milk or solid prey or body warmth to the nestlings. We have no observations of nests to confirm which of these processes is most significant, but we list hypotheses concerning the following four environmental cues that might control them: nutritional condition and energy balance; stress; availability of a key limiting resource or physiological cue; and foraging strategy.

\section{Nutritional condition and energy balance}

In mammals, many observations and experiments have demonstrated the complex links between nutrition, energy balance, and control of reproductive performance (Wade et al. 1996; Caprio et al. 2001). In the mink (Mustela vison) these links affect, among other things, implantation and early embryo development (Tauson 2001). Mink can maintain normal ovulatory function over a wide range of body mass and fat content, and nutritional infertility becomes a real danger only when energy balance is seriously impaired. For example, of four females held in negative energy balance, reproduction was switched off only in the leanest onc (Tauson et al. 2000). In Steller sea lions (Eumetopias jubataus), which, like stoats, have a $100 \%$ conception rate every year followed by a prolonged embryonic diapause, undernourished females had less chance of carrying a foetus to term, reducing the birth rate to $63 \%$ (Pitcher et al. 1998). The fat indices we recorded gave little evidence of starvation among the adult stoats we sampled in January 2001, and only 1 of 63 carcasses had no food remains in its gut, yet their birth rate was $0 \%$. This suggests that their failure to produce young could be due to a mechanism that is more complex than simple food deprivation.

\section{Stress}

Food deprivation also induces a varicty of separate and independent physiological and behavioural responses (Wade et al. 1996). Experimental manipulation of these responses demonstrates that infertility can be brought on by stress alone, correlated with, for example, social pressure or excessive exercise (Warren and Perlroth 2001), without necessarily causing mortality in adults. The stoats we observed were sampled during the decline phase of the beech cycle, when home ranges were large (Murphy and Dowding 1995; Purdey 2002), hunting demanded more physical effort, and stressful, aggressive social interactions were much more likely to arise. Such stress may be sufficient to cause already-fertilized adults to abort their young without necessarily (or at least not immediately) killing the adults themselves.

\section{Availability of a key limiting resource or physiological cue}

Mice are not the only food of stoats in New Zealand beech forests, but when mice are abundant after a seedfall, so are other prey species such as birds, insects and rats ${ }^{2}$

${ }^{2}$ A statement apparently refuting the role of rats in King (2002, p. 232) was included in error and should have been deleted. 
(Murphy and Dowding 1995). On the other hand, both quantity and quality of nutrition are important in determining fertility in all female mammals. Food of insufficient quality or the absence of a key requirement during the critical season can prevent adults from reproducing without affecting their body mass or fatness (Wade et al. 1996; White 2002). In this model, therefore, mice could function either as indicators of food quantity in general or as providers of some unidentified physiological cue that is required to prime the neuroendocrine pathways linking the metabolic and reproductive axes (Schiöth and Watanobe 2002). Our observation that variation in the spring mouse-density index alone explains over $60 \%$ of the variation in productivity of female stoats in summer is consistent with the possibility that stoats are better able to derive this cue from breeding mice than from substitute foods. The existence of such a cue, which is not necessarily a nutrient, might be predicted in small rodent-specialist predators that depend on matching reproductive effort to the prospects of success in a harsh northern environment (King 1989).

In the case of stoats, we have found no experimental evidence to support this idea, but there is some evidence in the case of a congeneric species with a similar evolutionary background, the least weasel (Mustela nivalis). Sundell (2003) reported on a 5-year study in Finland in which 65 litters of young least weasels were bred in captivity. In an experiment in 1999, six females were fed a diet of rodents only $(85 \%$ voles, either live or freshly killed, and the rest defrosted laboratory mice), and all mated, whereas two of seven fed only defrosted chicks did not mate. One of each group that did mate failed to give birth, but of those that did, the five females fed on rodents tended to produce larger litters (averaging 6.2 vs. 4.3 kits), with lower juvenile mortality (17 vs. $58 \%$ ) than the four females fed on chicks only. With larger samples, some of these differences might have been significant. These experiments are consistent with the view that when rodents are scarce, the chances of a least weasel (and presumably also a stoat) successfully producing young are reduced, even if other foods are available.

\section{Foraging strategy}

Young stoats are not able to control their own body temperature until they are at least 40 days of age (Segal 1975). When the female is away, they become hypothermic, and if their body temperature drops below $10-12^{\circ} \mathrm{C}$, they enter cold rigour, with arrested pulse and respiration. The young can survive so long as the female is not absent for too long too often, but their body growth ceases until she returns. When hunting is easy after parturition, not only can a female produce larger litters than usual (because of reduced intra-uterine mortality) but she can also minimize her foraging expeditions and spend most of her time in the nest warming the kits, thereby maximizing their growth rate. We have confirmed that the young of both sexes born in years when mice are abundant are not only more numerous but also grow larger than those born in other years (Powell and King 1997). Conversely, when mice are scarce, young stoats that survive to birth must be left unattended for longer, and the female must take more of her catch herself in order to meet the combined energy demands of lactation plus hunting over extended areas. Past a certain point, young left unattended and underfed for too long will not survive. This hypothesis therefore pro- poses that the reduction in the proportion of young when food is short is the consequence of increased mortality of offspring rather than of adults, which in turn produces the preponderance of infertile, surviving, but presumably stressed-out adults that we observed.

\section{Conclusion}

In southern beech forests in New Zealand, the reproductive success of female stoats varies with the abundance of mice, from the maximum physiologically possible during a mouse irruption, which typically follows 9 months after a beech seedfall, to total failure when the mice have disappeared by the next season 12 months later. This variation is due, we suggest, to the combination of two factors. Firstly, abundant breeding mice provide high-quality nutrients, perhaps including a significant metabolic cue, that are not obtainable in the same quantity from substitute foods during the same period in other years, which benefits intra-uterine processes. Secondly, a shift in foraging strategy of lactating female stoats benefits the survival (before and after birth) and growth rate of pre-independent young. Where rats are present they might add to the combined effect, although the correlation stands even where rats are absent. Conversely, a drastic shortage of mice in the following mouse crash year increases the mortality of embryos and nestlings, though the adult female stoats are able to survive, and remain relatively fat, on other foods. We suggest that these interactions could explain in large part the apparently disproportionate influence of mice on the variations in stoat population dynamics throughout the beech cycle in New Zealand, and we predict that similar relationships involving voles and lemmings govern the productivity of small mustelids in the northern hemisphere.

\section{Acknowledgements}

For financial support we thank the Waikato Branch, Royal Forest and Bird Society of New Zealand, the Lotteries Environment and Heritage Fund, the Royal Society (London), and the Universities of Waikato and York. The field study was undertaken with the approval of the University of Waikato Animal Ethics Committee and the permission of the Department of Conservation, Southland Conservancy. The procedures laid down by both institutions were developed in New Zealand, but are consistent with international ethical standards for research on animals and conform to the guidelines of the Canadian Council on Animal Care. For technical and logistical support during the field study we thank the Bioengineering Technologies group of HortResearch New Zealand (especially Rod McDonald and Phil Harris); Gary and Lyn Tong of Borland Lodge; and Peter Dilks (Department of Conservation). We thank P. Jamieson, D. Riddell, I. Southey, and K.R. Ayers for assistance in the field; Gary Matson for sectioning the teeth and reading the slides; Frank Bailey for preparing Fig. 1; and Rodney Mead, Marilyn Renfree, Murray Efford, Tom White, and two anonymous reviewer's for valuable comments on the manuscript.

\section{References}

Basse, B., McLennan, J.A., and Wake, G.C. 1999. Analysis of the 
impact of stoats, Mustela erminea, on northern brown kiwi, Apteryx mantelli, in New Zealand. WildI. Res. 26: 227-237.

Brommer, J.E., Pietiainen, H., and Kolunen, H. 2002. Reproduction and survival in a variable environment: Ural owls (Strix uralensis) and the three-year vole cycle. Auk, 119: 544-550.

Brown, J.A., and Miller, C.J. 1998. Monitoring stoat (Mustela ermineat control operations: power analysis and design. Sci. Conserv. 96: $1-21$.

Caprio, M., Fabbrini, E., Isidori, A.M., Aversa, A., and Fabbri, A. 2001. Leptin in reproduction. Trends Endocrinol. Metab. 12: $65-72$.

Choquenot, D., and Ruscoe, W. 2000. Mouse population eruptions in New Zealand forests: the role of population density and seedfall. J. Anim. Ecol. 69: 1058-1070.

Elliott, G.P., Dilks, P.J., and O'Donnell, C.F.J. 1996. The ecology of yellow-crowned parakeets (Cyanoramphus auriceps) in Nothofagus forest in Fiordland, New Zealand. N.Z. J. Zool. 23: 249-265.

Fitzgerald, B.M., and Gibb, J.A. 2001. Introduced mammals in a New Zealand forest: long-term research in the Orongorongo Valley. Biol. Conserv. 99: 97-108.

Fitzgerald, B.M., Daniel, M.J., Fitzgerald, A.E., Karl, B.J., Meads, M.J., and Notman, P.R. 1996. Factors affecting the numbers of house mice (Mus musculus) in hard beech (Nothofagus truncata) forest. J. R. Soc. N.Z. 26: 237-249.

Grue, H.E., and King, C.M. 1984. Evaluation of age criteria in New Zealand stoats (Mustela erminea) of known age. N.Z. J. Zool. 11: 437-443.

King, C.M. 1981. The reproductive tactics of the stoat (Mustela erminea) in New Zealand forests. In Proceedings of the First Worldwide Furbearer Conference, Frostburg, Md., 3-11 August 1980. Edited by J.A. Chapman and D. Pursley. Worldwide Furbearer Conference Inc., Frostburg, Md. pp. 443 468.

King, C.M. 1982. Age structure and reproduction in feral New Zealand populations of the house mouse (Mus musculus), in relation to seedfall of southern beech. N.Z. J. Zool. 9: 467-479 [with correction in Vol. 410].

King, C.M. 1983. The relationships between beech (Nothofagus sp.) seedfall and populations of mice (Mus musculus), and the demographic and dietary responses of stoats (Mustela erminea), in three New Zealand forests. J. Anim. Ecol. 52: 141-166.

King, C.M. 1989. The natural history of weasels and stoats. Christopher Helm, London.

King, C.M. 2002. Cohort variation in the life-history parameters of stoats Mustela erminea in relation to fluctuating food resources: a challenge to boreal ecologists. Acta Theriol, 47: 225-244.

King, C.M., and Edgar, R.L. 1977. Techniques for trapping and tracking stoats (Mustela erminea); a review, and a new system. N.Z. J. Zool. 4: 193-212.

King, C.M., and Moody, J.E. 1982a. The biology of the stoat (Mustela erminea) in the national parks of New Zealand. II. Food habits. N.Z. J. Zool. 9: 57-80.

King, C.M., and Moody, J.E. 1982b. The biology of the stoat (Mustela erminea) in the national parks of New Zealand. IV. Reproduction. N.Z. J. Zool. 9; $103-118$.

King, C.M., and Moller, H. 1997. Distribution and response of rats Rattus rattus, $R$. exulans to seedfall in New Zealand beech forests. Pac. Conserv. Biol. 3: 143-155.

Mappes, T., and Ylonen, H. 1997. Reproductive effort of female bank voles in a risky environment. Evol. Ecol. 11: 591-568.

Murphy, E.C., and Dowding, J.E. 1995. Ecology of the stoat in Nothofagus forest: home range, habitat use and diet at different stages of the beech mast cycle. N.Z. J. Ecol. 19: 97-109.

Murphy, E.C., and Pickard, C.R. 1990. House mouse. In The hand- book of New Zealand mammals. Edited by C.M. King. Oxford University Press, Auckland, New Zealand. pp. 225-242.

Norbury, G. 2000. The potential for biological control of stoats (Mustela erminea). N.Z. J. Zool. 27: 145-163.

O'Donnell, C.F.J., Dilks, P.J., and Elliott, G.P. 1996. Control of a stoat (Mustela erminea) population irruption to enhanee mohua (yellowhead) (Mohoua ochrocephala) breeding success in New Zcaland. N.Z. J. Zool. 23: 279-286.

Ostfeld, R.S., and Keesing, F. 2000. Pulsed resources and community dynamies of consumers in terrestrial ecosystems. Trends Ecol. Evol. 15: 232-237.

Paria, B.C., Reese, J., Das, S.J., and Dey, S.K. 2002. Deciphering the cross-talk of implantation: advances and challenges. Science (Wash., D.C.), 296: 2185-2188.

Pitcher, K.W., Calkins, D.G., and Pendleton, G.W. 1998. Reproductive performance of female Steller sea lions: an energeticsbased reproductive strategy? Can. J. Zool. 76: 2075-2083.

Powell, R.A., and King, C.M. 1997. Variation in body size, sexual dimorphism and age-specific survival in stoats, Mustela erminea (Mammalia: Carnivora), with fluctuating food supplies. Biol. J. Linn. Soc. 62: 165-194.

Purdey, D. 2002. New technology for the management of stoats (Mustela erminea), and analysis of a declining population in Fiordland, New Zealand. M.Sc. thesis, University of Waikato, Hamilton, New Zealand.

Renfree, M.B., and Shaw, G. 2000. Diapause. Annu. Rev. Physiol. 62: $353-375$.

Ruscoe, W. 2001. Advances in New Zealand mammalogy 19902000: the house mouse. J. R. Soc. N.Z. 31: 127-134.

Schiöth, H.B., and Watanobe, H. 2002. Melanocortins and reproduction. Brain Res. Rev. 38: 340-350.

Segal, A.N. 1975. Postnatal growth, metabolism, and thermore gulation in the stoat. Ekologia (Sverlovsk), 1: 38-44.

Sundell, J. 2003. Reproduction of the least weasel (Mustela nivalis nivalis) in captivity: basic observations and the influence of food availability. Acta Theriol. 48: 59-72.

Tabachnick, B., and Fidell, L.S. 1996. Using multivariate statistics. HarperCollins, New York.

Tauson, A.H. 2001. Links between nutrition and the reproductive axis in a seasonal breeder, the mink (Mustela vison). J. Reprod. Fertil. Suppl. 57: 97-101.

Tauson, A.H., Fink, R., Forsberg, M., Lagerkvist, G., and Wamberg, S. 2000. LH release in mink (Mustela vison): pattern of the LH surge and effect of metabolic status. Reprod. Nutr. Dev. 40: 229-247.

Ternovsky, D.V. 1983. The biology of reproduction and development of the stoat Mustela erminea (Carnivora, Mustelidae). [In Russian.] Zool. Zh. 62: 1097-1105.

Wade, G.N., Schneider, J.E., and Hui-Yun, L. 1996. Control of fertility by metabolic cues. Am. J. Physiol. 270: E1-E19.

Wardle, J. 1984. The New Zealand beeches: ccology, utilization and management. New Zealand Forest Service, Wellington.

Warren, M.P., and Perlroth, N.E. 2001. The effects of intense exercise on the female reproductive system. J. Endocrinol. 170: 3-11.

White, T.C.R. 2002. Outbreaks of house mice in Australia: limitation by a key resource. Aust. J. Agric. Res. 53: 505-509.

Wilson, P.R., Karl, B.J., Toft, R.J., Beggs, J.R., and Taylor, R.H. 1998. The role of introduced predators and competitors in the decline of kaka (Nestor meridionalis) populations in New Zcaland. Biol. Conserv, 83: 175-185.

Wright, P.L. 1942. Delayed implantation in the long-tailed weasel (Mustela frenata), the short-tailed weasel (Mustela cicognami), and the marten (Martes americana). Anat. Rec. 83: 341-353. 